\title{
The Production of Hairs on the Stems and Petioles of Tropaeolum peregrinum, L.
}

\author{
BY \\ ARTHUR W. HILL, F.L.S. \\ With Plate LVI and seven Figures in the Text.
}

THE common Canary-creeper or 'Canariensis' ${ }^{1}$ of gardens is generally mens grown in the British Isles or of material collected in South America preserved in herbaria fully bears out this assumption. Occasionally, however, it may be noticed that plants growing under favourable conditions show a very few hairs on young stems or petioles, but where they are growing normally and luxuriantly no traces of hairs can be seen, and the plants are absolutely glabrous.

In the summer of 1910, I noticed that some small plants of Tropaeolum peregrimum, growing in my garden, which had received injury to the leaf laminae, had developed a few hairs, and from this observation it seemed desirable to try and find out the cause of the production of hairs, and to ascertain the conditions under which it may be artificially induced. In the first case in which hairiness was noticed, snails were found to have eaten the laminae of the leaves more or less completely, leaving the young plants with only stems and bare petioles.

When making experiments the laminae were removed from healthy plants, and after an interval of a few days hairs were quite conspicuously developed on the young portions of the stem and on the young petioles. Experiments have been repeated during the past summer with greater care. Seedlings were grown until they had developed about ten leaves, and all the laminae were then removed; as each new leaf began to develop, its lamina was also removed, so that, except for the green stems and petioles, the plants were deprived of their main organs for assimilation and transpiration. Some of these plants so mutilated have been grown in the open, and some under a bell-jar in a moist atmosphere. It was found in August last (Aug. I9) that such plants developed hairs in the open in about four or five days, but

1 Tropaeolum canariense, Hort. T. aduncum, Sm. $=T$. peregrinum, L.

[Annals of Botany, Vol. XXVI. No. CII. April, 1912.] 
in September, both in the open and under the bell-jar, hairs were noticed on the formerly glabrous plants in three days' time (laminae removed 12 o'clock, Sept. I2, I9I I, examined Sept. I4, I9I I, and a few developing laminae removed, no hairs seen ; Sept. I5, I9I I, scattered hairs especially on younger parts. Rain fell on the night of I $3^{\text {th }}$ and air cool). Again, in October, the experiment was repeated during cold, dull, foggy weather (Oct. I4-16), and a plant under a bell-jar deprived of all its laminae developed a fairly dense felt of hairs on the younger parts in a space of three days. A similar plant in the open developed hairs, but to a less extent. Control plants with the laminae undisturbed, grown both in the open and under a bell-jar, showed no trace of hairs. It was noticed, however, that under a bell-jar a very few hairs were developed occasionally if the plant had been covered for about two weeks. The plants which had been stripped of their laminae were continued in this condition by removal of all developing leaves for about ten days, with the result that quite a dense felt of hairs was developed, clearly visible to the naked eye. In the case of the plants under a bell-jar the hairs were much longer than those of plants in the open, and hairs measured from $0.5^{-1} \mathrm{~mm}$. in length. If, after this copious development of hairs has proceeded for some days, the plant is again allowed to grow normally and the laminae are not removed, the production of hairs gradually diminishes, and in a short time ceases, with the result that the stems and petioles are again as glabrous as when the experiment was started. The hairy condition can be again induced in the growing portions by removal of the laminae, and the glabrous by their retention, so that by the alternate removal and retention of the laminae the hairy or glabrous condition may be produced. Should, however, the leaves which are allowed to form after a glabrous period be malformed and remain more or less aborted, the stem and petioles will still retain their hairy character.

On a plant which had been kept defoliated for some weeks under a bell-jar out of doors, it was noticed that hairs had developed on the midribs and under sides of the young leaves which were allowed to form at the end of October.

The hairs in $T$. peregrimum are unicellular, the outgrowth of a single epidermal cell. In a transverse section of the stem of a glabrous plant all the epidermal cells appear to be identical in character, and no cells can be distinguished as potential hair cells. When, however, hairs are about to be developed, certain epidermalcells become filled with dense granular contents, and such cells, at a slightly later stage, form small protruding papillae which will grow out to form the long unicellular hairs.

The full-grown hair has thin walls, and contains a copious supply of granular vacuolated protoplasm with a conspicuous nucleus suspended either near the base or towards the middle of the hair. The apex of the hair is rounded and slightly swollen, which makes it appear somewhat glandular, 
but this appearance is only due to the refractive character of the protoplasm at the tip of the hair.

The hair cells are seen to occupy a position comparable to that of the stomata in relation to the ordinary epidermal cells of the stem when a surface view or longitudinal section of the stem is examined. The epidermal cells are elongated, while the cell from which a hair arises is almost circular in outline. No such small cells could be seen except when a hair was either in process of formation or had already been formed. It would seem, there-

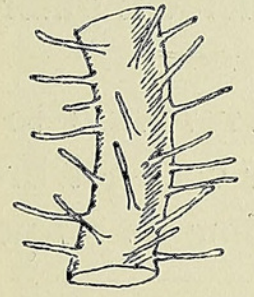

TEXT-FIG. I. A small piece of stem showing hairs.

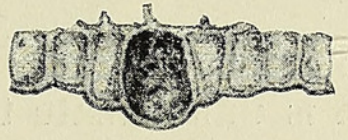

TEXT-FIG. 2. An epidermal cell, destined to become a hair, with dense granular contents.

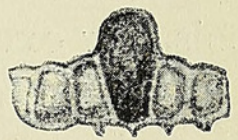

TEXT-FIG.3. A slightly later stage, the cell forming a papilla.

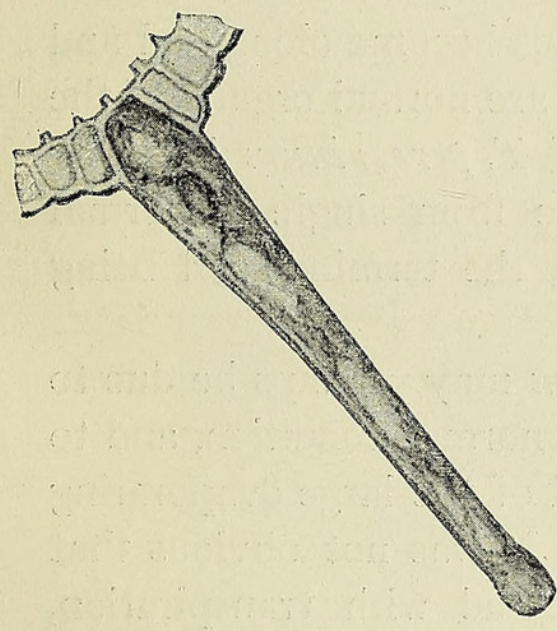

TEXT-FIG. 4. A fully developed hair with nucleus suspended near the base.

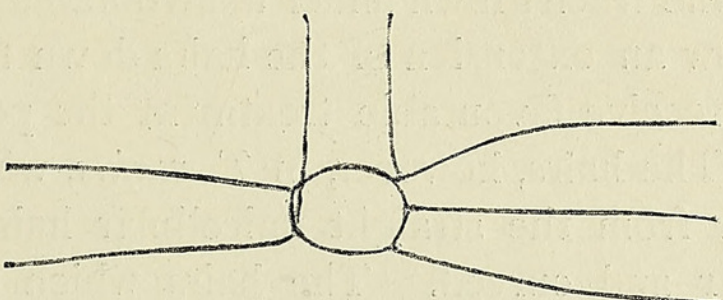

Text-FIG. 5. Surface view of an old piece of epidermis showing a small hair cell in optical section.

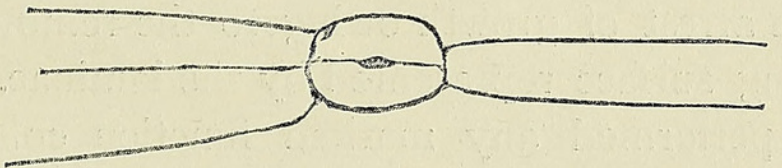

TeXT-FIG. 6. A stoma in optical section to compare with Fig. 5 .

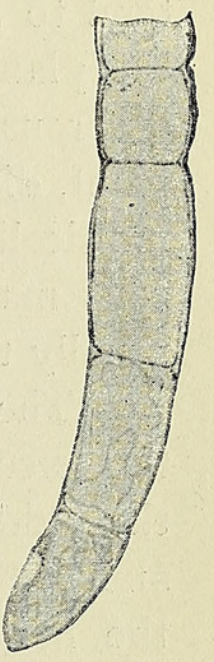

TEXT-FIG. 7. A young hair of Tro. paeolum majus.

fore, that the stimulus caused by the removal of the laminae induced division in some of the epidermal cells, and that one of the products of the division gives rise to a hair, while the other elongates to form an ordinary epidermal cell. Such cell-division appears to take place near the apex of the stem when the tissues are still quite young, but it is also clear that hair mothercells may be cut off from epidermal cells in older portions, as it has been noticed that the longer the plant is deprived of its laminae the denser the hairs become throughout the whole portion of the stem which is still capable of growth.

As far as I am aware very little has been done in the way of attempts 


\section{Hill.-Hairs on Stems, Ecc., of Tropaeolum peregrinum, L.}

to produce a hairy or glabrous condition, though characters of hairiness or the reverse are known to be variable ${ }^{1}$ among plants according to circumstances.

Vesque $^{2}$ discusses the development of hairs, and agrees with the theories of Kraus and Mer that the formation of hairs is due to the excess of nutritive matters and to the arrest in growth of the organs which carry them. He adds, 'Des plantes différentes sont plus ou moins propres à développer des poils sous l'influence du milieu. Tandis que certaines espèces deviennent velues au point d'être méconnaissables, je n'ai jamais réussi à faire développer un seul poil sur une plante réellement glabre, sur le pois, par exemple.'

Vesque would possibly not consider Tropaeolum peregrinum to be a truly glabrous plant, and it is unfortunate that his paper was not brought to my notice until it was too late to make similar experiments on peas to those made on the Canary-creeper.

It is of interest to notice that the allied species, Tropaeolum majus, the common 'nasturtium' of gardens, is always hairy on the under surfaces of the leaves, and when grown under unfavourable conditions the starved plants tend to show an extension of the hairs down the short petioles. But when the plants receive favourable treatment the petioles become elongated and glabrous. The hairs, however, in T. majus, which are normal organs of the plant, differ from the straight unicellular hairs of $T$.peregrinum in being multicellular and curved. The hairs which arise from single epidermal cells may consist of from three to several cells, the terminal cell being usually the longest.

The cause of hair production in $T$. peregrinum may perhaps be due to the excess of water supplied to the plant in its abnormal condition, and to the sudden arrest of growth owing to the removal of the large evaporating and growing surface represented by the laminae. It was not obvious that the hairs performed any marked function connected with transpiration, though it may well be that they represent the plant's efforts to provide a substitute for the large transpiring surfaces which it has lost.

\section{EXPLANATION OF PLATE LVI.}

A photograph of the upper part of a plant deprived of its laminae and showing a considerable development of epidermal hairs. Slightly enlarged.

1 Yapp on Spiraea Ulmaria. Brit. Assoc., Portsmouth, I9I1.

${ }^{2}$ Sur les causes et sur les limites des variations de structure des végétanx. M. J. Vesque, in Ann. agronomique, vol. ix, pp. 495-6. 


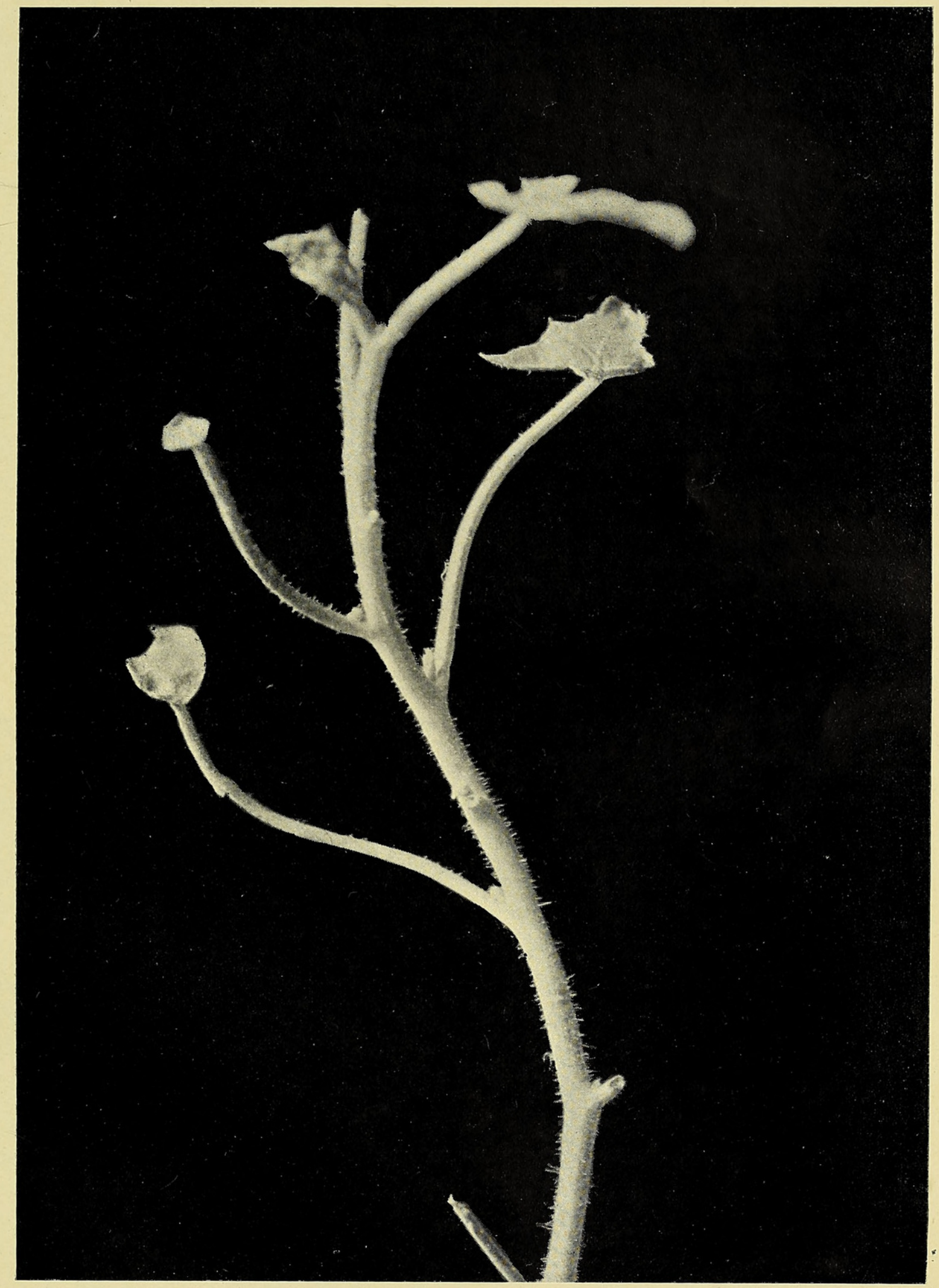

HILL - TROPAEOLUM. 


\section{$2 \mathrm{BHL}$ Biodiversity Heritage Library}

Hill, Arthur William. 1912. "The production of hairs on the stems and petioles of Tropaeolum peregrinum, L." Annals of botany 26, 589-592. https://doi.org/10.1093/oxfordjournals.aob.a089402.

View This Item Online: https://www.biodiversitylibrary.org/item/236773

DOI: https://doi.org/10.1093/oxfordjournals.aob.a089402

Permalink: https://www.biodiversitylibrary.org/partpdf/319916

\section{Holding Institution}

Smithsonian Libraries

\section{Sponsored by}

Biodiversity Heritage Library

\section{Copyright \& Reuse}

Copyright Status: Not in copyright. The BHL knows of no copyright restrictions on this item.

This document was created from content at the Biodiversity Heritage Library, the world's largest open access digital library for biodiversity literature and archives. Visit BHL at https://www.biodiversitylibrary.org. 